\title{
COMPOSITA W POLSKIEJ TERMINOLOGII EKOLOGICZNEJ
}

\author{
Nataliia Kasianchuk \\ Lecturer, Lesya Ukrainka Volyn National University, Ukraine \\ e-mail: nataliakasianchuk@gmail.com,orcid.org/0000-0003-4421-6906
}

\section{Streszczenie}

W obliczu zagrożeń powodowanych przez działalność człowieka dyskurs ekologiczny aktualnie jest jednym z najczęściej powoływanych tematów na świecie (przy czym w Polsce nieco rzadziej). Powszechnie propagowane idee ochrony środowiska naturalnego stanowią $\mathrm{z}$ jednej strony element dyskusji naukowej, z drugiej zaś - polemiki potocznej. Ze względu na fakt zaś, że czasu na podjęcie zdecydowanych działań w tym zakresie jest (jak udowadniają naukowcy) coraz mniej, temperatura dyskursu rośnie. Wskaźnikiem coraz bardziej emocjonalnego podejścia do debaty ekologicznej mogą być composita pojawiające się w obszarze społecznościowym, których analiza jest głównym celem prezentowanego tekstu.

Słowa kluczowe: ekologia, dyskurs publiczny, derywaty, composita, termin ekologiczny.

\section{DOI https://doi.org/10.23856/4306}

\section{Wprowadzenie}

Niektóre właściwości ekosystemów i sama koncepcja ekosystemu są wskazywane jako podstawa do zdefiniowania obszaru badań zwanego ekologią. Problemy, metody, narzędzia i podejścia ekologii są brane pod uwagę przy definiowaniu zadań, problemów i szkoleniu ekologów systemów. Problematyka ta generuje interdyscyplinarny charakter badan. Przykłady metod, koncepcji i zastosowań pochodzą z różnorodnej literatury dotyczącej ekologii, zarządzania zasobami naturalnymi i matematyki, która interdyscyplinarny charakter ekologii dodatkowo ilustruje. Mimo, że problematyka związana z ekologią pojawia się w dyskursie publicznym pod koniec XIX wieku - dopiero na przełomie wieku XX i XXI stała się niemal codziennie poruszanym zagadnieniem. „Ernest Haeckel, który w 1886 r. utworzył wyraz ‘ekologia’, nie mógł przepuszczać, że stanie się on jednym z odznaczających się najróżnorodniejszymi zabarwieniami polityczno-ideologicznymi haseł tego wieku" (D. Birnbacher, 1993). Termin 'ekologia' współcześnie cechuje się różnymi zabarwieniami znaczeniowymi, które niezwykle daleko sięgają poza pierwotne znaczenie (nadane mu w roku 1886). Neologizm ten przekraczając granice nauk przyrodniczych, wkroczył do nauk społecznych, humanistyki, ekonomii, inżynierii itd. Przeniesienie tego pojęcia stało się tak swobodne, że pojawiły się żądania ochrony tego słowa przed nawykowymi nadużyciami. Dzieje się tak częściowo dlatego, że termin „ekologia” jest zwyczajnie wyrażeniem modnym (Wróblewski, 1999). Celem prezentowanego tekstu jest dokonanie analizy composita występujących w ramach dyskursu ekologicznego o zabarwieniu - jak wskazano w tytule - rewolucyjnym, czyli oddającym rosnącą presję związaną z koniecznością podejmowania natychmiast zdecydowanych działań na rzecz ochrony środowiska naturalnego. Materiałem badawczym w tym przypadku były złożenia odnalezione w powoływanych źródłach, a ich katalog został poszerzony o analizę composita pojawiających się w mechanizmie wyszukiwania najpopularniejszego portalu społecznościowego w Polsce. Założeniem bowiem było dokonanie nie tylko analizy dyskursu naukowego, ale i potocznego. 


\section{Tło i model}

Komunikacja polega w przypadku dyskursu na temat ekologii na zderzaniu się różnych dyskursów w negocjowaniu znaczeń, zwłaszcza w odniesieniu do konotacji rozumianej jako pragmatyczna, dotycząca relacji między użytkownikami znaków a samymi znakami (Steciag, 2008). Środki masowego przekazu wiele uwagi poświęcają różnym kwestiom środowiskowym, takim jak zanieczyszczenie powietrza, dziura ozonowa, choroby przemysłowe, zmiany klimatyczne, życie roślin i zwierząt w ekosystemach, różnorodność gatunków i kwestie wymierania, które kształtują postawy ekologiczne społeczeństwa w skali lokalnej i globalnej (West $i$ in., 2003). W ten sposób powstają wspólnoty ludzi myślących podobnie, a co więcej, społeczności komunikacyjne posługujące się określonym dyskursem (Grzmil-Tylutki, 2000). Ponieważ termin 'dyskurs' jest nieco niejednoznaczny i wywołuje dyskusję metodologiczną, należy zauważyć, że na potrzeby prezentowanego artykułu jest on rozumiany w sensie poststrukturalnym, jako narzędzie komunikacji charakteryzujące się specyficznym dla danej społeczności użyciem języka i związany z kontekstem społecznym w taki sposób, że funkcjonuje w innych konkurencyjnych społecznościach komunikacyjnych, tworząc własne modele (Steciag 2008). Konkurencja dotyczy osiągnięcia hegemonii w opisywaniu świata poprzez zawłaszczanie znaków, a co więcej, tendencji i zachęcania innych do przyjęcia określonego sposobu myślenia (Bugajski, 2006).

Postrzeganie ekologii w Polsce uległo znacznej ewolucji w ciągu ostatnich dwóch dekad. Te zmiany świadomości społecznej są spowodowane głównie oddziaływaniem mediów, które w szerokim zakresie poruszają różnorodne zagadnienia ekologiczne, kształtując postawy ekologiczne zarówno na poziomie globalnym, jak i lokalnym. Efektem tego procesu jest pojawienie się wspólnoty społecznej podzielającej podobne przekonania, a w konsekwencji pojawienie się wspólnoty mowy posługującej się określonym dyskursem. W świadomości społecznej można zaobserwować poważną zmianę, ponieważ ekologia nie jest już postrzegana jedynie jako gałąź nauki, ale raczej jako wyraz podstawowych potrzeb człowieka: przyszłości ludzkości i życia na Ziemi w ogóle. Ekolodzy są zwykle uznawani za aktywistów walczących o ochronę środowiska, a nie za naukowców zamkniętych w swoich laboratoriach (Sztumski, 1999). Przyczyną tych zmian w świadomości społecznej mogą być zarówno ogólnie rozumiane zagrożenia dla przyszłości cywilizacji, mające istotny wpływ na warunki życia, jak i popularyzacja ekologii przez różne osoby lub organizacje aktywnie uczestniczące w debacie publicznej. Ponadto światowe media oferują szeroki zakres różnorodnych zagadnień ekologicznych, od zanieczyszczenia powietrza, dziury ozonowej, chorób cywilizacyjnych, żywności modyfikowanej genetycznie, wzrostu populacji, globalnego ocieplenia i zmiany klimatu, po zagrożone ekosystemy oraz gatunki fauny i flory kształtujące postawy ekologiczne, zarówno na poziomie globalnym i lokalnym (West i in., 2003). Chociaż tematy środowiskowe nie są (i nigdy nie były) na pierwszym miejscu w polskiej debacie publicznej, w wyniku tego procesu pojawia się społeczność społeczna o podobnych przekonaniach, a co za tym idzie - społeczność językowa posługująca się określonym dyskursem (Steciag, 2010). Dyskurs ekologiczny można wyobrazić sobie dość wąsko jako posiadający specyficzne cechy, które odróżniają go od innych form zachowań komunikacyjnych i które są ograniczone do społeczności językowej ludzi, którzy interesują się ekologią i opisują świat za pomocą własnego systemu poznania i interpretacji. Cechą charakterystyczną jest wysoki poziom świadomości ekologicznej, rozumianej powszechnie jako odpowiednia postawa ludzi wobec środowiska naturalnego, oparta na specjalistycznej wiedzy i silnych przekonaniach oraz systemie wartości, które są motorem ich działania (Papuziński, 2006). Szeroko rozumiany dyskurs środowiskowy, w którym temat wydaje się 
odgrywać pierwszoplanową rolę, można zdefiniować jako „całość tekstów (rozumianych jako dające się oddzielić i ustrukturyzowane sekwencje wypowiedzi pisanych lub mówionych), w których relacja między człowiekiem a środowiskiem naturalnym jest definiowana publicznie, tj. w mediach, lub w których omawia się wpływ działalności człowieka na środowisko i jej konsekwencje dla ludzi" (Jung, 2001).

Kwestie środowiskowe są coraz częściej przedstawiane w jednym z centralnych pól dyskursu (przede wszystkim w mediach). Nie oznacza to jednak, że takie historie silnie oddziałują na masową publiczność lub generują nową perspektywę spojrzenia na świat. Dyskurs ekologiczny jako gatunek ma poznawczy charakter mozaikowy, fragmentaryczny, chaotyczny i niesystematyczny. Rzadko opiera się na głębszej analizie czy logicznej argumentacji, aby stworzyć poważny artykuł publicystyczny. W efekcie można odnieść wrażenie, że kwestie środowiskowe nie są poważne, ale dziwne lub po prostu zabawne, patrząc z ogólnie dominującej perspektywy. Nie ulega wątpliwości, że taki sposób prezentacji nie sprzyja kształtowaniu świadomości ekologicznej. Poszerzonej wiedzy o przyrodzie, ekosystemie i harmonijnym funkcjonowaniu człowieka i przyrody powinna towarzyszyć wrażliwość moralna (na poziomie jednostki i społeczeństwa), która wpływa na relacje między ludźmi, cywilizacją i przyrodą. Nie można jednak zaprzeczyć, że choć przefiltrowane przez przepisy o masowej komunikacji, przyzwyczajenia językowe ulegają zmianie (Papuziński, 1997).

We współczesnych systemach słowotwórczych języków słowiańskich, w tym języka polskiego, można zauważyć wysoką aktywność nowego modelu słowotwórczego, na podstawie którego powstają liczne złożone wyrazy (zwłaszcza rzeczowniki) z pierwszym elementem obcym. Status tego typu słów jest obecnie przedmiotem badań wielu językoznawców, a pozycje prezentowane w różnych opracowaniach nie są jednolite, zwłaszcza w odniesieniu do pierwszego składnika złożeń, o których mowa będzie w dalszej części prezentowanego tekstu. Niewątpliwie jednak konstrukcje te mnożą się i są coraz częściej potwierdzane zarówno w odmianach językowych wspierających wyspecjalizowane obszary działalności człowieka (polityka europejska, informatyka, dyskurs ekologiczny itp.), jak i w języku mediów. Słowa te często przenoszą się z języka angielskiego na inne języki w formie odpowiednich zapożyczeń. Aktualnie obserwuje się pojawienie się serii pojęć, które nie mają obcych odpowiedników i niewątpliwie powstają na rodzimej ziemi. Na aktywność nowego modelu słowotwórczego wywiera wpływ kilka ważnych czynników, które powodują zmiany zachodzące w otaczającej rzeczywistości. Nie ulega również wątpliwości fakt, że źródłem tych zmian najpewniej jest proces postępującej globalizacji, który generuje dominującą rolę języka angielskiego w mechanizmach komunikacji (Długosz, 2015). Globalizacja bezsprzecznie wspiera unifikację wielu przejawów ludzkiej działalności. Zmienia się również proces komunikacji. Następuje przewartościowanie roli języka w sytuacji komunikacyjnej. Produktywność omawianego modelu słowotwórczego w wielu językach słowiańskich wskazuje również na pewne przejawy unifikacji językowej, zwane niekiedy przejawami słowotwórczości w językach słowiańskich (Waszakowa, 2005; Dtugosz, 2011).

\section{Composita}

Złożenie w rozumieniu słownikowym to stałe powiązanie dwóch lub więcej wyrazów zachowujących samodzielność gramatyczną i znaczeniową, ale tworzących wspólnie nową jednostkę semantyczną, najczęściej nazwę (Głowiński, Sławiński, 2010). W języku funkcjonują różne rodzaje compositów - w języku polskim zestawienia to niemal zawsze osobne wyrazy, czyli konstrukcje analityczne, zdecydowanie rzadziej (jak np. w języku niemieckim) syntetyczne 
(Altman, 2016). Do tej pory ciąg słów będących przedmiotem badań analizowano w języku polskim jednak także z wykorzystaniem strukturalnego i semantycznego aparatu metodologicznego. Zwrócono uwagę na strukturę związków, status pierwszego z członków związków, relacje między członami oraz konstrukcję słownikowej definicji pierwszego z członów kompozycji, często opartą o parafrazę formacyjną (słowotwórczą). W mniejszym stopniu badania koncentrowały się na normatywnych i tekstologicznych aspektach funkcjonowania composita (Dlugosz, 2012). Pojawiają się też pierwsze próby kognitywnej interpretacji znaczenia, polegające na zastosowaniu encyklopedycznych metod semantyki, uwzględniających wszystkie aspekty wiedzy i doświadczenia, w tym przede wszystkim kontekst sytuacyjny (Waszakowa, 2003; Dlugosz, 2013). Badania tekstologiczne przeprowadzone na composita z pierwszym zdezintegrowanym obcym pokazują, że tego typu złożone struktury, choć tworzone w oparciu o prosty schemat, charakteryzują się wysokim stopniem gęstości semantycznej. Wyodrębnienie wszystkich elementów znaczeniowych często nie jest możliwe jedynie w oparciu o definicję strukturalno-semantyczną, na wiązkach cech semantycznych składników kompozycji i relacji motywacyjnej między nimi. Aby oddać całą treść bogactwa złożonych słów z elementami występującymi w dyskursie o ekologii, należy wziąć pod uwagę czynniki pozajęzykowe, które nie wynikają z czysto formalnej struktury słowa i nie są określone pod względem składu (Dlugosz, 2015). Semantyka encyklopedyczna zaproponowana w modelu gramatyki poznawczej pozwala na aktualizację większej liczby cech należących do językowego obrazu wybranego elementu rzeczywistości zawartego w danej złożonej strukturze. Opiera się ona na założeniu, że procesy konceptualizacji zachodzące w ludzkim umyśle sięgają do różnych poziomów świadomości, wywodzą się z doświadczenia umysłowego oraz z wszelkiego rodzaju zdolności umysłowych lub zgromadzonej w nim wiedzy. Zatem na znaczenie wyrażenia językowego składa się także pewna dodatkowa struktura wynikająca $\mathrm{z}$, umysłowego dostępu do otwartego zbioru wiedzy dotyczącej danego przedmiotu lub zjawiska" (Langacker, 2009). Z poznawczego punktu widzenia istotne wydaje się postawienie problemu, czy polskie i bułgarskie związki z 'ekokomponentem' powtarzanym w serii wyrazów można uznać za semantyczne jednostki języka. Zgodnie z założeniami gramatyki poznawczej jednostkami języka są tylko te struktury, które spełniają warunek swego rodzaju automatyzacji, czyli taką strukturę można uznać za stałą (zrutynizowaną) w danej społeczności językowej do tego stopnia, że jej użycie nie wymaga od mówcy wysiłku budowania za każdym razem od nowa, ale pozwala odtworzyć całość (formę i znaczenie) poprzez przywołanie określonego wzoru (Langacker, 2009).

\section{Composita w treściach o problematyce ekologicznej}

Puryści językowi postulują ścisłe rozumienie pojęcia ekologii. Według tego podejścia zróżnicowanie i niejednorodność kontekstów użycia tego pojęcia jedynie pozornie nastręczać może problemów. O ile jednak w komunikacji naukowej można odwoływać się do standardowych definicji (rządzących) pojęciem ekologii i wymagać szacunku dla tych ustaleń, o tyle trudno jest wysunąć podobny postulat użytkownikom języka potocznego (Cottle, 2011; Ha, Fang, 2012; Pearman i in., 2008; Riedlinger, Rea, 2015). We francuskiej szkole analizy dyskursu tekst uważa się za produkt dyskursu, natomiast analiza dyskursu ma polegać na poszukiwaniu śladów dyskursu w tekście. Oznacza to, że dyskurs każdorazowo wiąże się z interpretacją tekstu, ale także z jego budowa może być przezeń determinowana. Konstrukcja bowiem tekstu lokuje go w ramach określonego dyskursu. Wiąże się to z faktem, że komunikowanie polega na ciągłej aktualizacji dyskursu, a rolą odbiorcy tekstu jest rozpoznanie tła w postaci dyskursu w danym przekazie. Tekst jest w takim razie pewną strukturą znaczeniową, której 
odczytanie (zrozumienie) wymaga dostępu do dyskursu, co staje się możliwe dzięki kontekstowi właśnie (Płowens, 2017; Jenkins, 2004). Pojęcie 'ekologia' nabiera w dialogu nowych znaczeń, a użytkownicy języka potocznego nie są skłonni do przejmowania znaczeń słów zdefiniowanych przez ekspertów. Niejednoznaczność w języku naukowym i potocznym nie zawsze jest wadą, którą należy usunąć za wszelką cenę. Ważne jest, aby w tym przypadku zaistniała potencjalna niejednoznaczność, czyli sytuacja, w której kontekst wypowiedzi ujednoznacznia rozumienie niejednoznacznego terminu. Tak wszechstronna (wielowątkowa) ewolucja tego pojęcia spowodowana jest nie tylko chęcią nawiązania do żargonu naukowego, którym ma być uszlachetnianie, ale przede wszystkim użyciem źródłowego znaczenia terminu ekologia w języku naukowym, oraz korzystanie ze słownika języka ekologii (Wróblewski, 2004). Dyskurs o ekologii nie jest prowadzony jako wierne przedstawienie, ale jest interpretacją tematycznego fragmentu rzeczywistości na różne sposoby, deformując obraz źródłowy. Informowanie reprezentuje bowiem hegemoniczną perspektywę poznawczą, określoną przez powszechne postrzeganie świata, opartą na codziennych doświadczeniach, dostępną dla wszystkich członków społeczności komunikatywnej (Steciąg 2009). Jeśli dodać do tego coraz większą presję społeczną na kwestie środowiskowe można mówić o rewolucji ekologicznej. Rewolucja ekologiczna jest terminem powoływanym w literaturze - najczęściej jednak definicja pojęcia tego opiera się o dyskurs naukowy (w tym polityczny i ekonomiczny) (Gellert, 2010; Foster, 2010; Foster, 2017; Skinner, Kinderman, Mashburn, 2019).

Zarejestrowane w rezultatach wyszukiwania composita o rewolucyjnym charakterze pojawiają się raczej rzadko (na 90 rekordów tych związanych z presją społeczną w zakresie dyskursu ekologicznego pojawiło się 27, z czego 7 się powtarzało - o czym dalej). Kilka z rezultatów wyszukiwania na podstawie analizy jakościowej autor zakwalifikował do terminologii „rewolucyjnej” (tabela poniżej).

Tabela 1

Wyniki analizy

\begin{tabular}{|l|l|c|}
\hline \multicolumn{1}{|c|}{ Kategoria } & \multicolumn{1}{c|}{ Composita } & Ilość rekordów \\
\hline \multirow{3}{*}{$\begin{array}{l}\text { Odnoszące się do organizacji czy systematyki } \\
\text { działania }\end{array}$} & ekosystem & 5 \\
\cline { 2 - 3 } & ekomachina & 1 \\
\cline { 2 - 3 } & ekostrajk & \multicolumn{1}{c|}{4} \\
\cline { 2 - 3 } & ekomechanizm & 7 \\
\hline \multirow{2}{*}{ Odnoszące się do zagrożenia } & ekopatrol & 2 \\
\cline { 2 - 3 } & ekostraż & 1 \\
\cline { 2 - 3 } & ekowarta & 10 \\
\hline \multirow{2}{*}{ Odnoszące się do nacisku } & ekopresja & 1 \\
\cline { 2 - 3 } & ekojazda & 9 \\
\hline \multirow{2}{*}{ Odnoszące się do protestu } & ekostrajk & 6 \\
\cline { 2 - 3 } & ekobunt & 3 \\
\cline { 2 - 3 } & ekoprotest & 1 \\
\hline Odnoszące się do ocen & ekoświry & 11 \\
\cline { 2 - 3 } & ekoterror & \multicolumn{2}{|c|}{} \\
\hline
\end{tabular}

Źródło: Opracowanie własne

W analizie pod uwagę zostały wzięte wyłącznie composita w języku polskim. Wszystkie $\mathrm{z}$ ujętych $\mathrm{w}$ analizie composita pojawiają się $\mathrm{w}$ organizacyjnych profilach. W pierwszej 
kategorii zdiagnozowano nośniki w postaci profili grup, organizacji, stowarzyszeń, które w celach działalności (bardziej lub mniej zorganizowanej) deklarują dbałość o środowisko naturalne. Podobnie w przypadku określeń odnoszących się do zagrożenia - composita w tym ujęciu stanowią albo nazwę profilu albo tytuł akcji przeprowadzanych przez poszczególne organizacje publikujące treści na wybranym portalu społecznościowym. Hasła związane z wyrażaniem nacisku z kolei pojawiały się częściej na portalach osób prywatnych - choć powiązanych z kilkoma organizacjami, których rekordy dotyczyły najczęściej. Na szczególną uwagę zasługuje w tej kategorii hasło 'ekojazda' - rozumiane w prezentowanym na profilu kontekście może być odczytywane jako swego rodzaju groźba. To samo określenie (oczywiście) pojawiło się również w kontekście ekologicznego użytkowania pojazdów spalinowych, ale ze względu na cel nakreślony we wstępie rekordy wynikające $\mathrm{z}$ tego kontekstu nie były brane pod uwagę. Wspomniane (niemal te same organizacje) często powołują się na złożenia wyrażające protest - tu najczęściej pojawiały się w kontekście strajku klimatycznego młodzieży. W zakresie kategorii określeń odnoszących się do ocen również pod uwagę zostały wzięte wyłącznie te, dotyczące charakteru rewolucyjnego - to istotne zastrzeżenie, bowiem na wybranym portalu społecznościowym występuje również profil o nazwie „Ekoświry”, ale w kontekście informacji publikowanych na nim należy stwierdzić, że chodzi nie o rewolucjonistów w omawianym tu sensie (prostestu, buntu), ale w rozumieniu ludzi 'pozytywnie zakręconych'.

$\mathrm{Z}$ dokonanej na potrzeby prezentowanego tekstu zatem analizy (krótkiej i przy użyciu możliwie prostego narzędzia w postaci wyszukiwarki profilowej) zarysowała się jednak obecność rewolucyjnej 'ekoterminologii' - począwszy od słabego w natężeniu emocjonalnym organizowania się ludzi i wywierania nacisków (w założeniu: pokojowych), aż po działalność bardziej zdecydowaną w swoim wydźwięku (wspomniana 'ekojazda' czy działalność 'ekoterrorystów').

\section{Podsumowanie}

Współczesny świat charakteryzuje się niezwykle szybkimi zmianami. W wyniku postępu, którego nie można zatrzymać, nieustannie pojawiają się nowe problemy ekologiczne i społeczne. Zjawisko wyraźnie widoczne jest w sferze informacyjnej społeczeństw, zwłaszcza społeczeństw wysoko rozwiniętych. Stąd często obserwowane są debaty, dyskusje i kampanie perswazyjne obecne w przestrzeni publicznej, ukierunkowanych na zwiększenie świadomości ekologicznej i promowanie postaw proekologicznych. Z kolei zmiany w środowisku wpływają na język, który również podlega dynamice. Nowe zjawiska, problemy, idee i koncepcje wymagają nazwania, a to generuje konieczność poniekąd tworzenia nowych pojęć. Pod tym względem język polski wykazuje wyraźną tendencję do lawinowego wzrostu liczby i częstotliwości słownictwa odnoszącego się do szeroko rozumianych zagadnień ekologicznych. Procesowi temu bacznie przyglądają się przedstawiciele krytycznego nurtu nowej dyscypliny, która powstała na styku ekologii i języka, czyli ekolingwistyki. Jednym z najczęściej w literaturze przytaczanych aspektów badań wydaje się analiza słownictwa ekologicznego, kluczowych dla tej dziedziny leksemów, ich funkcjonowania w dyskursie ekologicznym, ich konotacji, kolokacji itp. $\mathrm{O}$ ile proces adaptacji języka do zmian jest naturalny i jest zjawiskiem innym niż tworzenie swego rodzaju nowomowy w warunkach językowej 'poprawności ekologicznej', to zgodnie z założeniami większości ekolingwistów należy go rozumieć jako 'budowanie krytycznej świadomości języka', który ma odpowiadać zmieniającemu się sposób postrzegania problemów ekologicznych i ich miejsca w życiu człowieka i społeczeństw (Steciag, 2008). Tak czy inaczej proces ekologizacji języka postępuje, czego rezultatem jest problematyka poruszana $\mathrm{w}$ 
prezentowanym tekście. Funkcjonowanie pojęcia ekologii w języku naukowym i potocznym jest ciekawym przykładem tego, jak w dialogu specjalistycznym (naukowym) i spontanicznym (w życiu codziennym) słowo zaczyna nabierać nowych znaczeń, a mimo to partnerzy dialogu są w stanie je zrozumieć (Wróblewski, 2004).

Chociaż działania zmierzające w kierunku zapewnienia bezpieczeństwa ekologicznego to tematy wszechobecne w dyskursie publicznym i choć ich zasadniczym celem jest osiągnięcie proekologicznej transformacji, czyli rozwoju trwałego, zdawać należy sobie sprawę, że dyskurs ekologiczny dotyczy coraz bardziej naglących problemów. Przyjrzawszy się wybranemu wycinkowi polskiej rzeczywistości językowej w dyskursie społecznym - właściwie społecznościowym (czyli w praktyce wyrazom złożonym z komponentem 'eko-'), można stwierdzić, że racjonalnością ekologiczną niekiedy staje w tyle za rewolucyjną. Obie płaszczyzny analizowanego dyskursu jednak dotyczą niezwykle istotnych kwestii społecznych, nie powinna więc dziwić rosnąca temperatura analizowanego rodzaju dyskursu.

\section{Bibliografia}

Altmann J. (2016). Niemieckie composita jako jednostki słowotwórcze nacechowane kulturowo w przekładzie na język polski, Przekłady Literatur Słowiańskich, 7, 327-350.

Birnbacher D. (1993). Ekologia, etyka a nowe formy działań. Filozofia i ekologia w poszukiwaniu nowego stosunku do przyrody, Folia Philosophica, 10, 61-89.

Bugajski M. (2006). Język w komunikowaniu. Wydawnictwo Naukowe PWN, Warszawa

Cottle S. (2011). Taking Global Crises in the News Seriously: Notes from the Dark Side of Globalization. Global Media and Communication, 7(77), 77-95. doi:10.1177/1742766511410217 Długosz N. (2012). Normatywny aspekt compositów z pierwszym członem obcym w językach polskim i bułgarskim. Studia Slavica - Slovanské Studie, 16, 141-149.

Długosz N. (2013). Kognitywna interpretacja najnowszych złożeń z powtarzalnym w serii wyrazów członem związanym (na przykładach z języka polskiego i bułgarskiego). Slavia Meridionalis. 13, 187-200.

Dtugosz N. (2015). Język jako narzędzie kształtowania postaw proekologicznych - o polskich i bułgarskich złożeniach z komponentem eko- w dyskursie publicystycznym. Poznańskie Studia Slawistyczne, 8. doi: 10.14746/pss.2015.8.21

Foster J.B. (2010). Why Ecological Revolution? Monthly review, 61(8), 2-9. doi: 10.14452/ MR-061-08-2010-01_1

Foster J.B. (2017). The Long Ecological Revolution. Monthly review, 69(6), 11-21. doi: 10.14452/MR-069-06-2017-10_1

Gellert P.K. (2010). The Ecological Revolution: Making Peace with the Planet. Contemporary Sociology, 39(4), 444-445. doi: 10.1177/0094306110373238q

Głowiński M., Sławiński J. (2010). Słownik terminów literackich. Zakład Narodowy im. Ossolińskich, Wrocław.

Grzmil-Tylutki H.(2000). Francuski i polski dyskurs ekologiczny w perspektywie aksjologii. Wydawnictwo UJ, Kraków

Ha L., Fang L. (2012). Internet Experience and Time Displacement of Traditional News Media Use: An Application of the Theory of the Niche. Telematics and Informatics, 29(2), 177-86. doi:10.1016/j.tele.2011.06.001

Jenkins H. (2004). The Cultural Logic of Media Convergence. International Journal of Cultural Studies, 7(1), 33-43. doi:10.1177/1367877904040603 
Jung M. (2001). Ecological Criticism of Language [w:] The Ecolinguistic Reader. Language, Ecology and Environment, A. Fill, P. Muhlhauser (red.). Continnum, London - New York, 270-285.

Langacker W.R. (2009). Gramatyka kognitywna. Universitas. Kraków Papuziński A. (1997). Modele świadomości ekologicznej [w:] Światopogląd i ekologia. J. Dębowski (red.). UWM, Olsztyn, 100-109.

Papuziński A.(2006). Świadomość ekologiczna w świetle teorii i praktyki (Zarys politologicznego modelu świadomości ekologicznej). Problemy Ekorozwoju, 1, 33-40.

Pearman P. B., Guisan A., Broenniman O., Randin C. F. (2008). Niche Dynamics in Space and Time. Trends in Ecology \& Evolution, 23(3), 149-58. doi:10.1016/j.tree.2007.11.005

Ptowens J. (2017). Charakterystyka wzajemnych powiąań tekstu z duskursem. Ling Varia, 1(23), 61-76. doi: 10.12797/LV.12.2017.23.04

Riedlinger M., Rea J. (2015). Discourse Ecology and Knowledge Niches: Negotiating the Risks of Radiation in Online Canadian Forums, Post-Fukushima. doi:10.1177/0162243915571166 Skinner E., Kinderman T., Mashburn A.J. (2019). Ecological Revolutions. Lifespan Developmental Systems, 81-90. doi: 10.4324/9780429446122-8

Steciag M. (2008). Environmental Discourse on the Onet.pl Web Portal. Studia Medioznawcze, 4(35), 59-68.

Steciag M. (2010). Environmental Discourse in Public Debates in Poland: Relativization, Exclusion and Acceptance. Language and Ecology, 3(2), 1-16.

Steciag M. (2012). Dyskurs ekologiczny w debacie publicznej. Oficyna Wydawnicza Uniwersytetu Zielonogórskiego, Zielona Góra.

Sztumski W. (1999). Zmiany ustrojowe i rozwój świadomości ekologicznej [w:] Ekologia a procesy transformacji. J. Dębowski (red.). Wyższa Szkoła Pedagogiczna, Olsztyn, 111-117.

West B.M., Greenberg M.R., Sachsman D.B., Rogers R.M., Lewis M.J. (2003), The Reporter's Environmental Handbook. Rutgers University Press, New Brunswick-London

Waszakowa K. (2003). Kognitywne aspekty tworzenia nowych derywatów słowotwórczych (na przykładzie języka polskiego) [w:] Komparacja systemów i funkcjonowania współczesnych języków słowiańskich. Słowotwórstwo/Nominacja, I. Ohnheiser (red.) Universität Innsbruck, Opole, 411-435.

Waszakowa K. (2005). Przejawy internacjonalizacji w słowotwórstwie współczesnej polszczyzny. Wydawnictwo Uniwersytetu Warszawskiego, Warszawa

Wróblewski Z. (1999). Zarys metodologicznej charakterystyki filozofii ekologicznej. Roczniki Filozoficzne, 47(3), 153-159.

Wróblewski Z. (2004). Uwagi o rodzinie znaczeń pojęcia 'ekologia'. Państwo i Społeczeństwo, IV(2), 153-162.

Zacher L.W. (2011). Wymiary dyskursu ekologicznego - przegląd problemów i wybranej literatury. Problemy Ekorozwoju, 2(6), 83-92. 